flavour of national pride. Alternative entertainment was normally provided, also showing the culture of the country. The high-lights of the week were probably the performance of Dvorak's "Rusalka" in the National Theatre and the traditional Symposium dinner in the Wallenstein Palace.

In retrospect one can sum up the Symposium as being one of the most successful yet held and certainly the best organized. The standard which was set is one which will be found difficult to equal, but it is hoped that something approaching this technical perfection will be reached in other countries, both west and east of the Iron Curtain, in future international symposia.

\section{THE LIBRARY ASSOCIATION ANNUAL CONFERENCE}

$I^{\mathrm{N}}$ $\mathrm{N}$ his presidential address to the Library Association on September 17 on the theme of "Knowledge and Education", Dr. J. Bronowski said that a civilized society must preserve what its best minds discover, but preservation alone does not make it an educated or even a cultured society. Moreover, an educated society could exist only when knowledge is not merely stored but is also shared, and it was the invention of printing that made the book an instru. ment of education. Dr. Bronowski drew on his own experience to illustrate the role that libraries can take in education and above all in self-education, but in science the public libraries have scarcely played that part at all : if they are to do so, they must have the books to enable them to make the language of science familiar to those who are not professional scientists. Besides the classics of literature, we need many more new classies of science--books like those of Sherrington, Eddington and Schrödinger, which looked at new discoveries in a personal way and spoke to the non-scientist through their personal tone and philosophy. He urged the publication of the old and new classics of seience in a single series, which he believed would be widely bought and read and would make the language of science familiar to a new generation, showing them the concepts of science for what they are, classical creations which rank among the permanent monuments to the human imagination. He did not think that the printed book was the last instrument of education we would discover, but he was sure that the printed book and the public library would remain the most powerful means for selfeducation.

Dr. Bronowski's address found echoes in several of the addresses which followed. Mr. A. Shaw Wright's review of the thirty years work of the County Libraries Section of the Library Association, in referring to the work of the regional bureaux, to the "Readers' Guides", to the international exchanges of assistants and the help of the Carnegie United Kingd sm Trust, indicated also the way in which the county libraries contributed to this work of self-education. It was implicit also in the discussion of the problems of the school library which Mr. E. Blishen introduced under the title "The Reluctant Reader", and it was sounded explicitly by Mr. J. C. Harrison in his "Retrospect and Forecast of Education for Librarianship and Professional Status". Admittedly controversial on some points, Mr. Harrison mado a strong plea for well-educated and trained librarians if the public library is to be an effective instrument of education, and he claimed that at present it offered neither the status nor the remuneration which could attract or hold a sufficient number of those possessing the ability and knowledge required.

Dr. T. A. Margerison took up more specifically Dr. Bronowski's point in discussing the interpretation of science in an address to the reference and special libraries section on September 19. Dr. Margerison asserted that the average layman's ignorance of science was a danger to democracy, and stressed the need for more effective science teaching in the schools, for more writing for the layman by scientists of repute, and for more effective advice to librarians on the choice of scientific books. Mr. B. S. Page in reviewing university library development was concerned with a particular aspect, but his paper is of special interest to the scientist as such. Recalling the assertion of the University Grants Committee in its report of 1921 that an adequate library is not only the basis of all teaching and study but also an essential condition of research, Mr. Page discussed the implications for the university library of the post-war expansion of the universities. The two-fold function of the university library, of supporting both the teaching of the undergraduates and the creative work in scholarship or science of the postgraduate students and the university staff, was not at all easy to balance. Mr. Page emphasized the importance of the library representing to all, and not least to undergraduates, the unity and not the fragmentation of knowledge. The whole question of training the student in the use of the library required more study, and Mr. Page referred to the investigation into the adequacy of present library techniques to the needs of scholarship initiated by the Ford Foundation, and to the pilot survey which the Nuffield Foundation was conducting at Leeds in the use of books in a university library. Stressing the importance of the initiative of the library in connexion with general education, Mr. Page suggested that the university library should include a centre of disinterested reading, looking and listening, and that the right kind of help and the right atmosphere were what the student needed. On the expenditure side, Mr. Page said little. $\mathrm{He}$ pointed out that according to the University Grants Committee's returns for 1955-56, fifteen universities and university colleges spent on books and bindings a total of $£ 214,586$, or about the amount spent by Harvard University alone, the total for England, including Oxford and Cambridge, being $£ 487,786$, but he did not attempt to analyse expenditure or holdings in relation to expansion.

Of the remaining papers, Dr. C. W. J. Higson's review of the libraries of the university institutes of education should be mentioned.

\section{STRIVING FOR RIGOUR IN GREEK SCIENCE}

$\mathbf{N}$ an address delivered at Dublin to Section $A$ (Mathematics) of the British Association, entitled "The Striving for Rigour in Greek Science", Prof. C. Lanczos compared the standards of mathematical rigour set by the Greeks with the stand urds of to-day, and examined their claims to be regarded as complete in terms of the general Greek philosophical back- 